\title{
Unusual cause of bladder and urethral stones in a child
}

\author{
Gopal Sharma, Kalpesh Mahesh Parmar, Praveen Lanka, Shrawan Kumar Singh
}

Urology, Post Graduate Institute of Medical Education and Research, Chandigarh, India

\section{Correspondence to} Dr Kalpesh Mahesh Parmar, kalpesh010385@gmail.com

Accepted 28 November 2018

\section{DESCRIPTION}

A 12-year-old child presented to our hospital with dysuria for the past 4 years. He had a history of difficulty in voiding and multiple episodes of urinary retention needing catheterisation for the past 3 months. Parents denied any history of haematuria, pyuria or graveluria. He had undergone open cystolithotomy at the age of 4 years for bladder stones. Further details are not known of the procedure. $\mathrm{He}$ remained well for the next 8 years.

On examination, he was malnourished with body mass index of $12.5 \mathrm{~kg} / \mathrm{m}^{2}$. He was haemodynamically stable and afebrile. Abdominal examination was unremarkable except for the presence of scar from previous surgery. On blood investigations his haemoglobin was $10.6 \mathrm{~g} / \mathrm{L}$, total leucocyte count was $5 \times 10^{9} / \mathrm{L}$ and platelet count was $340 \times 109 / \mathrm{L}$. His sodium was $142 \mathrm{mmol} / \mathrm{L}$; calcium was $9.6 \mathrm{mmol} / \mathrm{L}$ and potassium $4.4 \mathrm{mmol} / \mathrm{L}$. His kidney function test was normal. Urine routine microscopy showed $8-10$ pus cells, urine $\mathrm{pH}$ was 6.2 and culture showed growth of Escherichia coli. The patient received preoperative intravenous piperacillin tazobactam according to the culture report. Ultrasonography of the abdomen showed multiple echogenic lesions in the prostatic urethra

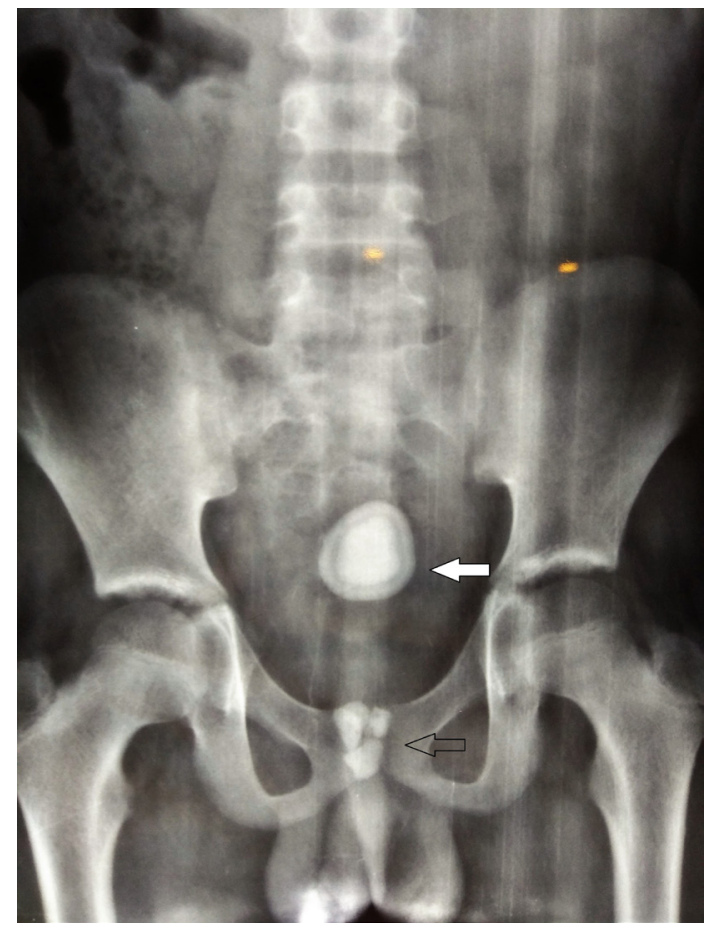

Figure 1 Plain X-ray film showing single bladder stone with 'skin of onion appearance' (solid white arrow) and multiple urethral stones (black arrow). with a calculus of size $3.5 \mathrm{~cm}$ in urinary bladder with mild increase in bladder wall thickness suggestive of cystitis. There was no stone in the kidney. Plain X-ray abdomen and pelvis showed a single radio-opaque show in bladder and multiple radio-opaque shadows in the prostatic urethra (figure 1). He underwent percutaneous cystolithotomy and intravesical access obtained using $30 \mathrm{~F}$ amplatz sheath. Intraoperatively on cystoscopy, multiple calculi were noted in the prostatic urethra attached to a suture and a single

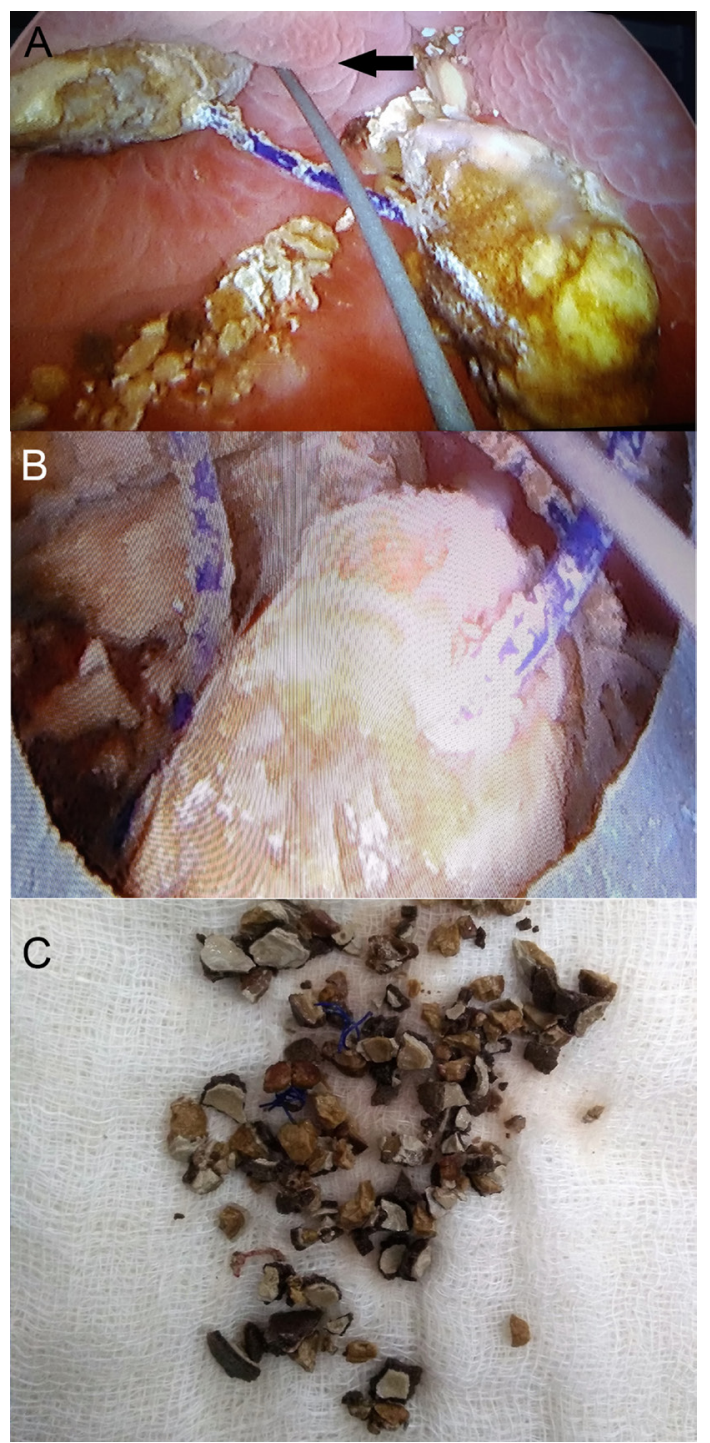

Figure 2 (A) Percutaneous cystoscopy showing multiple stones being pulled out of urethra through bladder neck (solid black arrow) into the bladder. (B) Multiple urethra stones around a suture. (C) Depicts the final amount of stones retrieved after the surgery. 
large calculus was noted in bladder attached to suture (figure 2). There was no stricture in the urethra. Urethral stones were pulled back into the bladder to facilitate lithotripsy. All the stones were fragmented and extracted using 24F nephroscope with help of lithoclast and grasper. Complete clearance of stones was achieved and all the non-absorbable sutures were also removed. A per-urethral and suprapubic catheter was left in situ. Suprapubic catheter was removed on postoperative day 4 and per-urethral catheter on day 6. Postoperative period was uneventful. The patient was discharged on postoperative day 7 . Stone analysis revealed ammonium urate and calcium oxalate stones. We plan to do metabolic workup of the patient 4-6 weeks later.

Bladder calculi occur rarely in children, and mostly occur due to migration of stone from kidney or due to various conditions leading to stasis of urine in bladder. ${ }^{1}$ There have been previous reports of bladder stones formation around non-absorbable used for herniorrhaphy, exstrophy repair, caesarian section, hysterectomy, prostatectomy and migration of meshes used in urinary stress incontinence surgery. ${ }^{2}$ The non-absorbable sutures retrieved from the stone in this case could have been used to close the bladder or anterior abdominal wall. This foreign body in the bladder resulted in the recurrent episodes of dysuria due to urinary tract infection and finally culminating into formation of calculi around it. Clinical diagnosis of bladder stones can be made by plain X-ray film as in this case, but for aetiological diagnosis high index of suspicion and careful history taking is required. Surgery remains the treatment of choice with complete clearance being the goal.

\section{Learning points}

- Primary vesicle calculi are rare in children and most of the times they are associated with some underlying pathologic process.

- Diagnosis can be made with plain X-ray films showing internal laminations (skin of onion appearance).

- Use of non-absorbable sutures should be discouraged for bladder repair and when used for other surgeries around bladder utmost care should be taken to avoid erosion into bladder wall.

Acknowledgements We sincerely thank the patient for being cooperative during hospital stay.

Contributors All authors have contributed equally to preparation of the manuscript. GS and KMP: manuscript design and concept. PL: data collection. SKS: revision and proofreading.

Funding The authors have not declared a specific grant for this research from any funding agency in the public, commercial or not-for-profit sectors.

Competing interests None declared.

Patient consent Obtained.

Provenance and peer review Not commissioned; externally peer reviewed.

\section{REFERENCES}

1 Thurston W, Wilson SR. Diagnostic ultrasound. 3th ed. USA: Mosby, 2005:321-94.

2 Mahdavi A, Mostafavi H. Hanging Bladder calculi Secondary to Misplaced Surgical Suture. Iran J Radiol 2015;12:e11303.

Copyright 2018 BMJ Publishing Group. All rights reserved. For permission to reuse any of this content visit

https://www.bmj.com/company/products-services/rights-and-licensing/permissions/

BMJ Case Report Fellows may re-use this article for personal use and teaching without any further permission.

Become a Fellow of BMJ Case Reports today and you can:

- Submit as many cases as you like

- Enjoy fast sympathetic peer review and rapid publication of accepted articles

- Access all the published articles

- Re-use any of the published material for personal use and teaching without further permission

For information on Institutional Fellowships contact consortiasales@bmjgroup.com

Visit casereports.bmj.com for more articles like this and to become a Fellow 